\title{
Effect of viral infection on sinking rates of Heterosigma akashiwo and its implications for bloom termination
}

\author{
Janice E. Lawrence ${ }^{1}$, Curtis A. Suttle ${ }^{2, *}$ \\ ${ }^{1}$ Department of Earth and Ocean Sciences, University of British Columbia, 6270 University Boulevard, \\ Vancouver, British Columbia V6T 1Z4, Canada \\ ${ }^{2}$ Departments of Earth and Ocean Sciences, Botany, and Microbiology \& Immunology, University of British Columbia, \\ 6270 University Boulevard, Vancouver, British Colombia V6T 1Z4, Canada
}

\begin{abstract}
Viruses play many important roles in the ecology of marine microbes, including that of mortality agents of phytoplankton. The widespread abundance of viruses in sediments, coupled with observations that some flagellated algae lose motility when infected, prompted this investigation into the fate of infected cells and the propagation of infection throughout a population in situ. We used 2 unrelated viruses that infect the bloom-forming alga Heterosigma akashiwo as model systems. Settling columns were used to determine the impact of viral infection on the vertical movement of H. akashiwo. Within $24 \mathrm{~h}$ following infection with HaRNAV 263 or H. akashiwo virus strain OIs1, 20.9 \pm 5.8 and $12.2 \pm 1.9 \%$ of the populations were sinking at rates of 1.25 and $0.73 \mathrm{~m} \mathrm{~d}^{-1}$, respectively. By $48 \mathrm{~h}$ post-infection approximately $50 \%$ of cells infected with either virus had lysed. As sinking cells would encounter decreasing levels of light in the natural environment, we incubated infected cultures in complete darkness and compared the length of the lytic cycle to that of cultures incubated under a L:D cycle. Again, approximately $50 \%$ of the population lysed by $48 \mathrm{~h}$, regardless of the light conditions or type of virus, and lysis of the entire population was complete by $144 \mathrm{~h}$. Based on these results, we propose that, depending on the characteristics of the water column, there are 3 potential fates for viruses from cells infected in situ. In water with a deep mixed layer (>8 m), lysis of infected cells would occur within the mixed layer and the infection would be propagated within the euphotic zone. If the water is relatively deep (100s of meters), and the mixed layer shallow $(<8 \mathrm{~m})$, cell lysis and viral release would occur below the mixed layer, where viral propagation would not occur. Finally, in shallow waters (10s of meters) lysis of infected cells would occur at the sediment surface, resulting in the accumulation of a high abundance of viruses.
\end{abstract}

KEY WORDS: Algal bloom termination $\cdot$ Algal virus $\cdot$ Heterosigma akashiwo $\cdot$ Sinking rates $\cdot$ Bloom dynamics

\section{INTRODUCTION}

Viruses play many important roles in marine microbial ecology. In addition to affecting community composition and diversity (Bratbak et al. 1996), nutrient cycling (Wilhelm \& Suttle 1999), and potentially, genetic transfer (Suttle et al. 1990), viruses are important agents of cell death for phytoplankton and may contribute to algal bloom dynamics (Suttle et al. 1990, Bratbak et al. 1993, Nagasaki et al. 1994, Suttle 2000).
Lytic viruses infect many bloom-forming species, including Aureococcus anophagefferens (Sieburth et al. 1988, Gastrich et al. 1998) Chrysochromulina sp. (Suttle \& Chan 1995), Emiliania huxleyi (Bratbak et al. 1993), Phaeocystis pouchetii (Jacobsen et al. 1996), Heterocapsa circularisquama (Taruntani et al. 2001) and Heterosigma akashiwo (Nagasaki et al. 1994, Lawrence et al. 2001, Tai et al. 2003). Although it is clear that viruses infect many bloom-forming species, little is known of the ecology of infected blooms. Most 
research to date has involved establishing that viruses are mortality agents for phytoplankton and, more recently, attempting to determine the extent of their effect.

Heterosigma akashiwo is a raphidophyte that episodically undergoes population explosions to form economically and environmentally detrimental blooms. These blooms are seeded by the germination of benthic resting cysts into flagellated phytoplankton (Yamochi 1984). Establishment of bloom-forming populations is correlated with increases in river run-off and the formation of a pycnocline (Yamochi 1989). These processes are believed to increase the availability of macronutrients, trace metals such as chelated iron and manganese, and Vitamin $\mathrm{B}_{12}$ in bottom waters (Yamochi 1989, Honjo 1992). Diel vertical migrations of up to $10 \mathrm{~m} \mathrm{~d}^{-1}$ allow $H$. akashiwo to form dense blooms under these conditions by exploiting deep nutrient pools (Yamochi \& Abe 1984). Thus, vertical migration is thought to be essential for bloom maintenance. The severity and duration of these blooms is unpredictable from year to year and the factors controlling them have remained elusive. However, the isolation of lytic viruses from areas where blooms are endemic indicates that viruses are involved in $H$. akashiwo mortality.

As with many species of bloom-forming algae, Heterosigma akashiwo is intermittently dormant between annual blooms and remains in the ecosystem by overwintering as resting cysts in sediments. Free virus particles are subject to various mechanisms of removal from the water column, such as adsorption to particulate matter, grazing by protists, UV decay, or decay by dissolved substances (Suttle \& Chen 1992, Gonzalez \& Suttle 1993, Noble \& Fuhrman 1997). Therefore, the annual maintenance of viral populations may be dependent on environmental reservoirs that permit free viruses to persist until they contact suitable hosts. As high abundances of H. akashiwo viruses have been detected in sediments where blooms are endemic (Lawrence et al. 2002), and in bottom waters during the decline phase of $H$. akashiwo blooms (Taruntani et al. 2000), sediments may provide a reservoir for viruses when their hosts are dormant. The mechanisms that result in the accumulation of viruses which infect $H$. akashiwo are not known. Hypotheses include deposition inside infected cells, adsorption to sinking particulate matter, and sinking inside faecal pellets. Sinking of infected cells would propably result in the highest pelagic-benthic transfer, since an individual cells can contain hundreds of thousands of viral particles (Lawrence et al. 2001); however, this has not been examined. Also, it is not known if viral replication can occur in infected algae under the dark conditions they would encounter while sinking through the water column.
We examined the effect of infection on the vertical movement of Heterosigma akashiwo and the impact of darkness on the lytic cycle. The goal was to determine whether infected cells would sink in the dark and, if so, whether viral replication would occur. H. akashiwo can be infected by at least 3 unrelated viruses (Nagasaki et al. 1994, Lawrence et al. 2001, Tai et al. 2003), and we took the opportunity to determine if populations infected with different viruses behaved similarly. These data were used to develop a conceptual model that describes the fate of infected cells in nature.

\section{MATERIALS AND METHODS}

Cultures. Heterosigma akashiwo Strain 522 (Northeast Pacific Culture Collection), originally isolated from English Bay, Vancouver, Canada, was used in all experiments. Cultures of $H$. akashiwo were maintained in f/2-enriched seawater (Guillard 1975) (30\%o) supplemented with $10 \mathrm{nM}$ sodium selenite under continuous light or a 14:10 h light:dark (L:D) cycle (260 $\mu \mathrm{mol} \mathrm{m} \mathrm{m}^{-2} \mathrm{~s}^{-1}$ photosynthetically active radiation), at $20^{\circ} \mathrm{C}$. Growth of the cultures was estimated by measuring in vivo chlorophyll fluorescence (Turner Designs fluorometer) over time.

Virus HaRNAV 263 was isolated from the Strait of Georgia, British Columbia (Tai et al. 2003). It is a ssRNA virus that replicates in the cytoplasm of Heterosigma akashiwo. Virus OIs1 was isolated from sediment samples taken from the Okeeover Arm of Malaspina Inlet, British Columbia (Lawrence et al. 2002). It was cloned by diluting the virus to extinction twice (Cottrell \& Suttle 1991). Virus stocks of each clone were produced by adding $0.1 \%(\mathrm{v} / \mathrm{v})$ viral lysate to exponentially growing $H$. akashiwo cultures and monitoring for algal lysis by in vivo chlorophyll fluorescence. Lysed cultures were filtered through glass-fibre filters (Whatman GFF, nominal pore size $=1.2 \mathrm{~mm}$ ) and polyvinylidine difluoride filters (Millipore, 0.45 - $\mu \mathrm{m}$ pore size), and the filtrate was stored at $4^{\circ} \mathrm{C}$ until use (within $48 \mathrm{~h}$ ).

Settling column experiments. Experiments were conducted using rapidly-growing cultures of Heterosigma akashiwo grown in $2.4 \mathrm{llow}$-form culture flasks under the conditions described above, except that illumination was provided from above on a $14: 10 \mathrm{~h}$ L:D cycle. Viral lysate was added $(1 \% \mathrm{v} / \mathrm{v})$ at $t=0$ to duplicate cultures. Duplicate uninfected cultures served as controls. Every $24 \mathrm{~h}, 6 \mathrm{~h}$ into the light period, each culture flask was gently mixed and $380 \mathrm{ml}\left(V_{\text {total }}\right)$ was carefully poured into a $50 \mathrm{~cm}$ tall $(L)$ Plexiglas ${ }^{\circledR}$ settling column (Bienfang 1981). At the same time, a $1 \mathrm{ml}$ sub-sample for determining the initial abundance of $H$. akashiwo $\left(A_{\text {init }}\right)$ was preserved with $10 \%$ Lugol's fixative, and a $50 \mathrm{ml}$ sub-sample 
fixed for transmission electron microscopy (TEM) with $1.5 \%$ glutaraldehyde in $0.2 \mathrm{M}$ cacodylate buffer and $0.1 \mathrm{M}$ sucrose (Lawrence et al. 2001). The settling columns were incubated with continuous overhead illumination under the temperature-controlled conditions described above. After $2 \mathrm{~h}(t), 50 \mathrm{ml}\left(V_{\text {bot }}\right)$ was drained from the bottom of the columns, and a $1 \mathrm{ml}$ aliquot was fixed with $10 \%$ Lugol's for determining the final abundance of sedimented cells $\left(A_{\text {bot }}\right.$ cells $\mathrm{ml}^{-1}$ ).

The abundance of Heterosigma akashiwo at $t=0$ $\left(A_{\text {init }}\right.$ cells $\left.\mathrm{ml}^{-1}\right)$ and in the sedimented fraction $\left(A_{\text {bot }}\right)$ were determined by counting a $0.1 \mathrm{ml}$ sample in a Palmer-Maloney chamber under $100 \times$ magnification.

The percentage of cells sedimented in a culture was determined using the following formula adapted from Bienfang 1981):

$$
\begin{aligned}
& \text { Percentage of } \\
& \text { sedimented cells (\%) }
\end{aligned}=\frac{\left(V_{\text {bot }} \times A_{\text {bot }}\right)-\left(V_{\text {bot }} \times A_{\text {init }}\right)}{\left(V_{\text {total }} \times A_{\text {init }}\right)}
$$

The sinking rate was then determined as:

$$
\begin{aligned}
& \text { Net sinking } \\
& \text { rate }\left(\mathrm{m} \mathrm{d}^{-1}\right)
\end{aligned}=\frac{\left[\left(V_{\text {bot }} \times A_{\text {bot }}\right)-\left(V_{\text {bot }} \times A_{\text {init }}\right) \times L\right]}{\left(V_{\text {total }} \times A_{\text {init }}\right) \times(t \div 24 \mathrm{~h})}
$$

Light:dark experiments. L:D experiments with Heterosigma akashiwo were conducted in $5 \mathrm{ml}$ borosilicate culture tubes. Exponentially growing cultures were divided into the following 4 treatments: uninfected L:D, uninfected dark, infected L:D, and infected dark. At $t=0$, cultures were inoculated with $1 \% \mathrm{v} / \mathrm{v}$ HaRNAV or OIs1 lysate and allowed to adsorb for 30 min under $260 \mu \mathrm{mol} \mathrm{m} \mathrm{m}^{-2} \mathrm{~s}^{-1}$ photosynthetically active radiation. Triplicate series of each treatment were then incubated under a 14:10 L:D cycle or constant darkness. Dark conditions were achieved by wrapping the culture tubes in 2 layers of aluminium foil and placing them in the L:D incubator. Growth and lysis was monitored by destructively sampling triplicate cultures from each treatment and measuring in vivo fluorescence. The relative biomass of infected cultures was determined by calculating the percentage of the fluorescence of infected cultures relative to the fluorescence of the control cultures (fluorescence infected $^{-}$ fluorescence ${ }_{\text {control }} \times 100 \%$ ).

Thin-sections of Heterosigma akashiwo prepared for TEM (Lawrence et al. 2001) were viewed with a Zeiss $10 \mathrm{C}$-TEM at an accelerating voltage of $80 \mathrm{kV}$. At each time point a minimum of 100 cells were examined and scored as infected if viral particles were visible in the cytoplasm and/or if the cytoplasm was vacuolated. Care was taken to ensure that cells were only examined once. The percentage of visibly infected cells was then calculated by dividing the number of visibly infected cells by the total number of cells examined and multiplying by $100 \%$.

\section{RESULTS}

Cell abundance in cultures of Heterosigma akashiwo infected with either HaRNAV or OIs1 increased during the first $24 \mathrm{~h}$ after inoculation with viral lysate and then began to decline (Figs. 1A \& 2A). By 48 h, approximately $50 \%$ of the cells in each treatment had lysed, and complete lysis had occurred by $96 \mathrm{~h}$. As there were no cells left to sample at $96 \mathrm{~h}$, there are no data points at that time point. Cell abundance in control cultures grown under the same conditions increased until the experiment was terminated $96 \mathrm{~h}$ post-inoculation (Figs. 1A \& 2A).

The net movement of uninfected Heterosigma akashiwo populations $6 \mathrm{~h}$ into the light period was towards the surface at approximately $0.7 \mathrm{~m} \mathrm{~d}^{-1}$, and was relatively consistent throughout the experiments. Within the populations infected with HaRNAV, $24 \mathrm{~h}$ after infection, $20.9 \pm 5.8 \%$ of the cells had sedimented
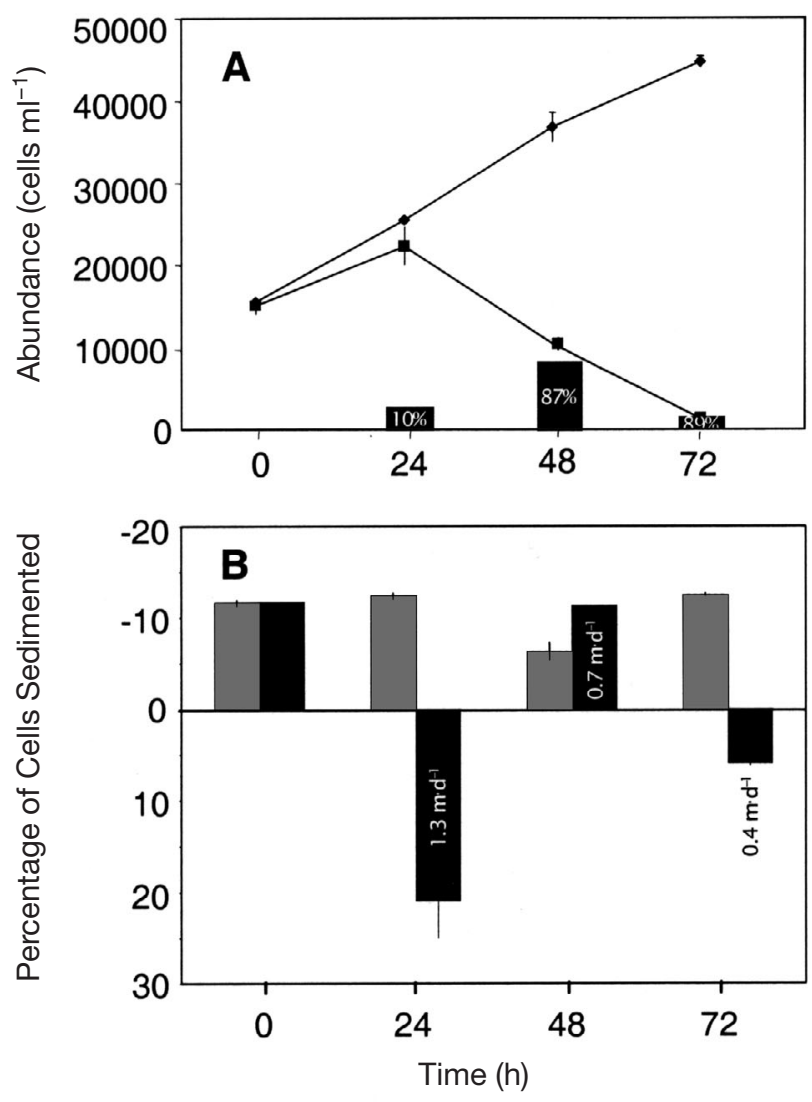

Fig. 1. Heterosigma akashiwo. (A) Cell abundance of uninfected $(\bullet)$ and HaRNAV-infected $(\bullet)$ cultures over time; percentages inside bars: percentage of infected population in which virus particles were visible by TEM. (B) Percentage of cells settled to the bottom in uninfected (grey) and HaRNAVinfected (black) cultures throughout lytic cycle; negative values indicate migration towards surface; positive values migration towards bottom. Values inside bars: sinking/ swimming rates of infected cultures. Error bars are range, $n=2$ 

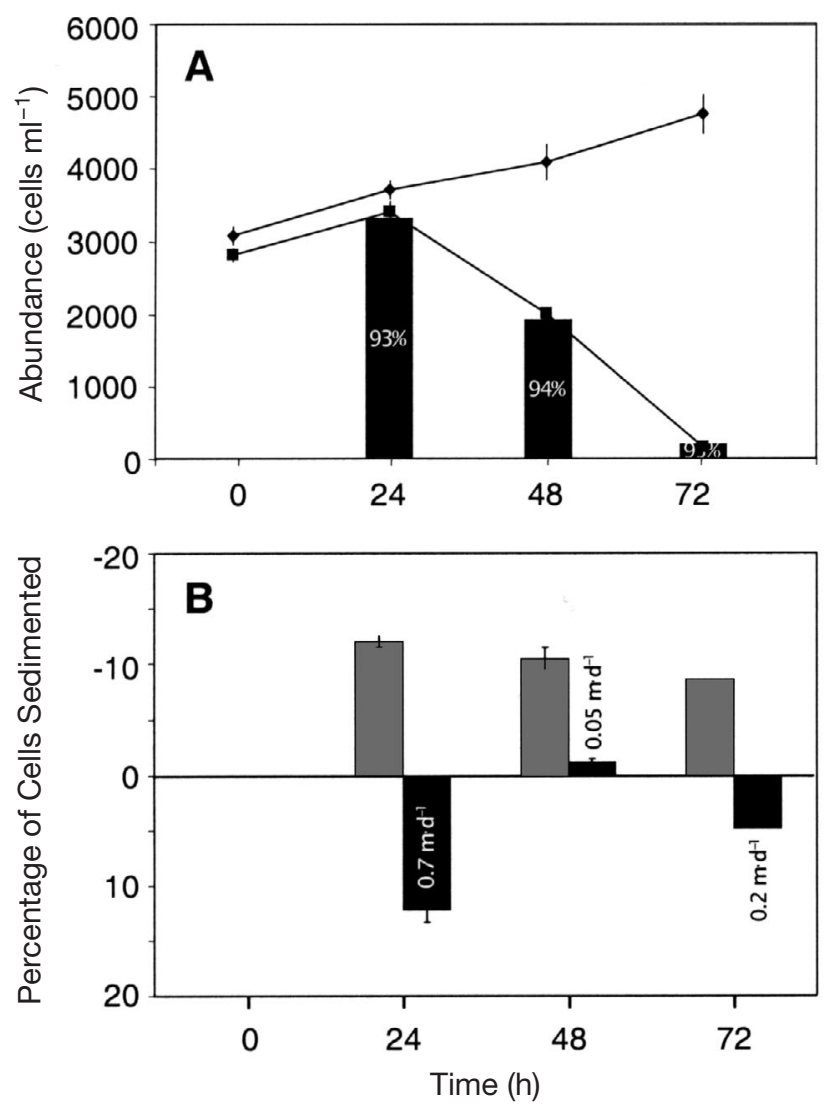

Fig. 2. Heterosigma akashiwo. (A) cell abundance of uninfected $(\bullet)$ and OIs1-infected ( $\bullet$ ) over time; (B) percentage of cells settled to bottom in uninfected (grey) and OIs1-infected (black) cultures throughout lytic cycle. Further details as in Fig. 1
Table 1. Heterosigma akashiwo. Percentage of visibly infected cells throughout lytic cycle determined by TEM. A minimum of 100 cells was examined at each time point, and graded as either visibly infected or uninfected by either HaRNAV or OIs1. Percentage of infected cells was calculated by dividing number of visibly infected cells by total number examined and multiplying by $100 \%$. p.i.: post-infection

\begin{tabular}{|lccc|}
\hline \multirow{2}{*}{ Virus } & \multicolumn{3}{c|}{ Visibly infected cells (\%) } \\
& 24 h p.i. & 48 h p.i. & 72 h p.i. \\
\hline HaRNAV & 10 & 87 & 89 \\
OIs1 & 93 & 94 & 95 \\
\hline
\end{tabular}

(Fig. 1B) at a rate of approximately $1.3 \mathrm{~m} \mathrm{~d}^{-1}$ while 12.2 $\pm 1.9 \%$ of cells infected with OIs1 were sinking (Fig. 2B) at a rate of ca. $0.7 \mathrm{~m} \mathrm{~d}^{-1}$. By $48 \mathrm{~h}$ the net movement of infected populations was towards the surface, at a rate of ca. $0.7 \mathrm{~m} \mathrm{~d}^{-1}$ for HaRNAV-infected cells, and $0.05 \mathrm{~m} \mathrm{~d}^{-1}$ for OIs1-infected cells. Net movement switched again to downwards $72 \mathrm{~h}$ post-inoculation, and $6 \pm 0.3 \%$ of populations infected with HaRNAV were sinking (Fig. 1B) at ca. $0.4 \mathrm{~m} \mathrm{~d}^{-1}$, while $4.8 \pm 0.4 \%$ of populations infected with OIs1 were sinking (Fig. 2B) at ca. $0.2 \mathrm{~m} \mathrm{~d}^{-1}$.

When incubated under L:D conditions, the relative fluorescence of HaRNAV- or OIs1-infected cultures began to decrease relative to that of control cultures $48 \mathrm{~h}$ after inoculation with viral lysate (Fig. 3A). Lysis of the entire population was complete $144 \mathrm{~h}$ after inoculation. The biomass of infected cultures incubated under continuous dark conditions also began to decrease relative to control cultures at $48 \mathrm{~h}$ (Fig. 3B), and lysis was complete by $144 \mathrm{~h}$.

Examination with TEM revealed that only $10 \%$ of cells infected with HaRNAV showed visible signs of infection $24 \mathrm{~h}$ post-infection (Table 1). At this time, $93 \%$ of cells infected with OIs1 were visibly infected. By $48 \mathrm{~h}$, infection could be detected visually in $87 \%$ of the HaRNAV- and $94 \%$ of the OIs1infected cells that were examined; however, it is important to note that $50 \%$ of the populations infected with either virus had lysed by this point (Figs. 1A \& 2A). Infection was visible in ca. $90 \%$ of the cells examined for either system by $72 \mathrm{~h}$ post-infection.

\section{DISCUSSION}

Vertical migration allows flagellated phytoplankton to acquire subsurface nutrients that are otherwise inaccessible to their non-migrating counterparts. Therefore, in
Fig. 3. Heterosigma akashiwo. (A) Biomass inferred by relative fluores-

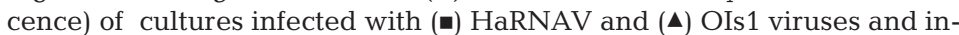
cubated under 14:10 h L:D conditions; (B) relative fluorescence of cultures infected with (๘) HaRNAV and (\) OIs1 viruses incubated the dark. Biomass expressed as a percentage relative to uninfected cultures; $n=3$ 
stratified water swimming is believed to be of competitive advantage to populations of flagellated over nonflagellated algae (Smayda 1998). Blooms of Heterosigma akashiwo occur under stratified conditions, and cells undergo daily migrations at 1 to $1.3 \mathrm{~m} \mathrm{~h}^{-1}$ (Yamochi \& Abe 1984) to reach nutrient-rich water up to $10 \mathrm{~m}$ deep (Smayda 1998). The results of this study indicate that once infected, $H$. akashiwo cells sink at rates of up to $1.3 \mathrm{~m} \mathrm{~d}^{-1}$. There are no other reports in the literature for sinking rates of virally infected phytoplankton. However, using Stoke's law we can calculate the theoretical sinking rate of an $H$. akashiwo cell:

$$
\omega_{\mathrm{s}}=\frac{\left(\rho_{\mathrm{s}}-\rho\right) g d^{2}}{18 \mu}
$$

where $\omega_{\mathrm{s}}$ is the sinking rate of a sphere (cell), $\rho_{\mathrm{s}}$ is the density of the sphere (assumed to be approximately the density of marine phytoplankton cytoplasm, $1065 \mathrm{~kg} \mathrm{~m}^{-3}$ (Smayda 1970), $\rho$ is the density of the fluid through which the sphere is falling $\left(1027 \mathrm{~kg} \mathrm{~m}^{-3}\right), g$ is the force of gravity $\left(9.8 \mathrm{~m} \mathrm{~s}^{-1}\right), d$ is the diameter of the sphere $\left(10^{-5} \mathrm{~m}\right)$, and $\mu$ is the molecular viscosity of seawater $\left(1.15 \times 10^{-3} \mathrm{~kg} \mathrm{~m}^{-1} \mathrm{~s}^{-1}\right.$; at $\left.20^{\circ} \mathrm{C}, 29 \mathrm{psu}\right)$. This calculation provides an estimate that non-motile $H$. akashiwo cells will only sink $\sim 0.2 \mathrm{~m} \mathrm{~d}^{-1}$ at $20^{\circ} \mathrm{C}, 29 \mathrm{psu}$. The estimated density for a $H$. akashiwo cell does not account for physiological and biochemical changes that may accompany infection. Also, the calculation does not account for other factors such as aggregation, which would result in more rapid sinking rates than those achieved by individual cells. These factors could result in a sinking rate more rapid than that calculated by Stoke's law, and may account for the difference between the observed sinking rate and the calculated sinking rate. Alternatively, factors such as altered behaviour (ie. downwards swimming) could also be responsible for the sinking rates observed in this study.

Lysis in both virus systems occurred from 48 to $96 \mathrm{~h}$. The infected populations could be divided into 2 subpopulations: one that started to sink at $24 \mathrm{~h}$, and one that started to sink at $72 \mathrm{~h}$ (Figs. 1 \& 2). While sample limitations did not allow us to verify that the sinking cells were actually infected, it is probable that all cells were infected since the number of viruses added to the cultures should have resulted in synchronous infection (authors' unpubl. data). This probably indicates that the progression of the lytic cycle is dependent on the host's cell cycle, as is the case for many virus-eukaryotic cell systems (Knipe 1996). In a synchronous culture growing at a rate of $1 \mathrm{~d}^{-1}$, as in this study, only a portion of the entire population would undergo mitosis each day, even though the cells that do undergo mitosis would do so at the same time. Therefore, the progression of the infection cycle, and therefore the onset of sinking, would be tied to the circadian cell cycle of the cultured population. Thus, the onset of sinking and cell lysis is likely to depend on host-cell physiological status, as well as the timing of viral infection.

Packaged OIs1 virus particles within infected Heterosigma akashiwo cells were visible with TEM $24 \mathrm{~h}$ post-infection, while viruses were not visible in cells infected with HaRNAV until $48 \mathrm{~h}$ post-infection. This was probably due to differences in the replication and viral packaging of these viruses. Therefore, examinations of visibly infected cells is not a reliable method for estimating the proportion of infected cells and virus-mediated mortality in natural populations of H. akashiwo. Moreover, infected cells will sink and therefore not be detected in surface populations. These results indicate that estimates of virus-mediated mortality of $H$. akashiwo in nature are not yet possible with current techniques.

Dark post-infection incubation did not inhibit lysis of Heterosigma akashiwo, nor did it alter the length of the lytic cycle for either virus system examined. As nucleic acid and protein synthesis are energy-consuming processes, $H$. akashiwo cells must either have sufficient energy stores to allow the lytic cycle to continue, or they must produce enough energy in the dark to drive these processes. Some cyanophage-host systems produce viruses in the dark, using energy from cyclic photophosphorylation and/or oxidative phosphorylation for viral synthesis (Padan et al. 1970, Sherman \& Haselkorn 1971, Adolph \& Haselkorn 1972, Allen \& Hutchison 1976, Bisen et al. 1988). The net result is that sinking infected cells will still undergo lysis in the dark and release progeny viruses into the environment.

Total population lysis in the L:D experiments did not occur until $144 \mathrm{~h}$ post-infection, while complete lysis was reached within $96 \mathrm{~h}$ during the sinking experiments. This difference was probably due to differing culture conditions, such as culture vessel and direction of illumination. This variability in the length of the lytic cycle suggests that environmental conditions and host physiology will affect the length of the lytic cycle in nature, and therefore also affect the depth of water an infected, sinking cell will reach prior to lysis. Variability in the length of the lytic cycle is therefore intrinsically linked to the fate of viruses in the ocean. Other factors that affect the sinking rate of infected cells will also impact the fate of viruses and their ability to propagate infection within a bloom. For example, aggregation has not been examined in infected Heterosigma akashiwo populations; however, it is well known to result in increased sinking rates of phytoplankton (Smayda 1970).

The detection of lytic viruses that infect Heterosigma akashiwo in the natural environment (Chan et al. 1998, 
Taruntani et al. 2000, Lawrence et al. 2001) indicates that viruses are mortality agents. However, the extent of virus-mediated mortality is not easy to determine. The results of this study indicate that viral control of blooming populations is complex, as it is dependent on a number of factors. The propagation of infection through a bloom depends on the fate of the virus and infected cells and the strain-specificity of the virus. It is also very dependent on the physical oceanographic conditions. We can hypothesise at least 3 potential outcomes for infection of $H$. akashiwo (Fig. 4):

Case I: In areas where the mixed layer is relatively deep, sinking cells may not reach the pycnocline prior to lysis. Under these conditions, progeny viruses would be released above the pycnocline where they could infect new cells and thereby propagate infection within the bloom. If these conditions persisted and/or the number of viruses available for infection was high enough, the bloom would terminate due to viral infection. This process may explain the detection of free virus particles in surface-water samples from the Strait

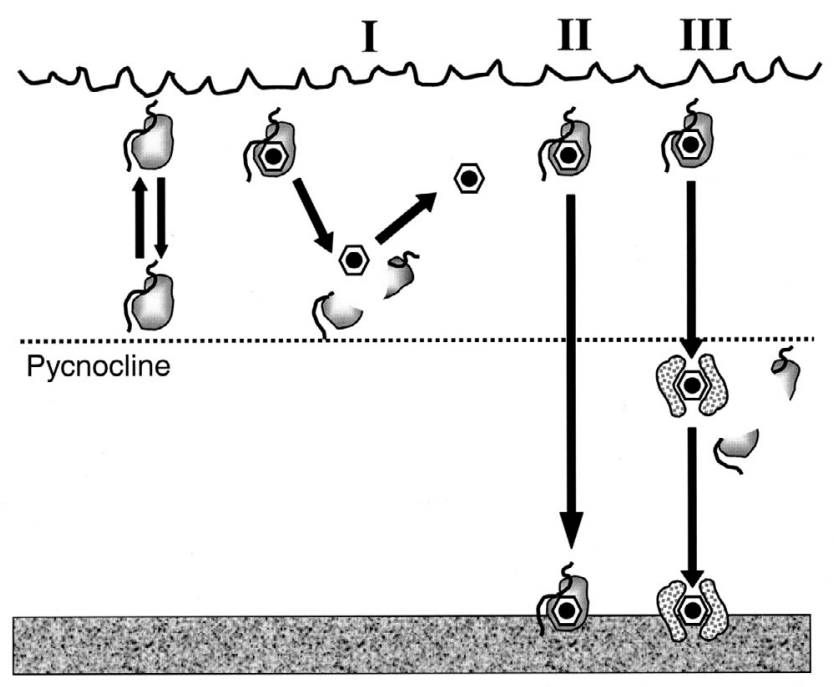

Fig. 4. Heterosigma akashiwo. Conceptual model depicting fate of virally infected cells and viruses that infect them. On the left, uninfected cells vertically migrate between surface and pycnocline. Depending on physical oceanographic conditions, infected cells and the viruses produced during infection succumb to 3 potential outcomes: In Case I, under highly stratified conditions or in areas where pycnocline is relatively deep, infected cells lyse above pycnocline and release progeny viruses where these may propagate infection within the bloom. In Case II, when infected cells are not retained within pycnocline and water column is relatively shallow, infected cells will reach the benthos prior to lysis, resulting in high abundances of viruses at the sediment-water interface. In Case III, infected cells are not retained within mixed layer but sink below the pycnocline where cell lysis occurs and the viruses are released, the released viruses are subject to various loss terms and may be adsorbed to particles and be transported to bottom of Georgia (Chan et al. 1998) and the association of visibly infected cells with bloom termination in Japanese waters (Nagasaki et al. 1994).

Case II: In very shallow environments, infected cells may sink to the bottom prior to lysis. Under these conditions, viruses would accumulate at the sediment surface and could be resuspended to infect future populations of algae. At the sinking rates and conditions of this study, infected cells could reach the benthos prior to lysis (within 96 to $144 \mathrm{~h}$ ) in a water column approximately 4 to $8 \mathrm{~m}$ deep. Under conditions that promote aggregation, sinking rates could be much higher, resulting in the transport of infected cells to much deeper sediments. This represents a rapid transport mechanism that could explain the abundance of infectious viruses (3210 agents $\mathrm{cm}^{-3}$ sediment) detected in shallow sediments, such as Malaspina Inlet (Lawrence et al. 2002), and the observed high concentration of infectious viruses near the sediment-water interface (Taruntani et al. 2000).

Case III: In deeper environments with a relatively shallow mixed layer, cells may sink below the pycnocline but not reach the sediments prior to lysis. This study has shown that, in darkness, lysis will continue in infected cells and produce infectious progeny viruses. This is an explains an increase in viral particles at the surface infecting Heterosigma akashiwo following deep tidal mixing (A. Chan \& C. Suttle unpubl data). Virus particles released below the pycnocline are still subject to losses such as adsorption to particles (Suttle \& Chen 1992, Noble \& Fuhrman 1997), grazing by protists (Suttle \& Chen 1992, Gonzalez \& Suttle 1993), or decay by dissolved substances (Noble \& Fuhrman 1997). Nonetheless, infectious virus particles are found in sediments collected at the deepest depths sampled (285 m) in the Strait of Georgia (Lawrence et al. 2002).

Phytoplankton mortality can be caused by numerous factors, including sedimentation, grazing (e.g. Walsh 1983), physiological stress due to nutrient or light limitation (Berges \& Falkowski 1998) and viral lysis (Suttle et al. 1990, Bratbak et al. 1993, Suttle 2000). Cellular mortality resulting in the decline of an entire population, or the termination of a bloom, however, is a very different and ultimately a more complex process than the mortality of individual cells. The models of the fate of infected cells and release of viral particles presented here emphasise that the interactions between virus and phytoplankton blooms are also very dependent on the physical environment.

Acknowledgements. We would like to thank A.M. Comeau, M. Henry, A.C. Ortmann, V. Tai and F.J.R. Taylor for helpful discussions, and P.J. Harrison for loan of the settling columns. This project was supported by Natural Sciences and Engineering Research Council of Canada Awards to J.E.L. and C.A.S. 


\section{LITERATURE CITED}

Adolph KW, Haselkorn R (1972) Photosynthesis and the development of blue-green algal virus N-1. Virology 47:370-374

Allen MM, Hutchison F (1976) Effect of some environmental factors on cyanophage AS-1 development in Anacystis nidulans. Arch Microbiol 110:55-60

Berges JA, Falkowski PG (1998) Physiological stress and cell death in marine phytoplankton: Induction of proteases in response to nitrogen or light limitation. Limnol Oceanogr 43:129-135

Bienfang PK (1981) SETCOL-a technologically simple and reliable method for measuring phytoplankton sinking rates. Can J Fish Aquat Sci 38:1289-1294

Bisen PS, Audholia S, Shukla HD, Gupta A, Singh DP (1988) Evidence for photosynthetic independence of viral multiplication in cyanophage LPP-1 infected cyanbacterium Phoridium uncinatum. FEMS Microbiol Let 52:225-228

Bratbak G, Egge JK, Heldal M (1993) Viral mortality of the marine alga Emiliania huxleyi (Haptophyceae) and termination of algal blooms. Mar Ecol Prog Ser 93:39-48

Bratbak G, Wilson W, Heldal M (1996) Viral control of Emiliania huxleyi blooms? J Mar Syst 9:75-81

Chan AM, Baur M, Mah W, Suttle CA (1998) Preliminary characterization of a lytic pathogen for Heterosigma akashiwo and its distribution and abundance in coastal waters of British Columbia, Canada. Abstracts of the 8th Int Symp on Microbial Ecology, Halifax, Nova Scotia, p 121

Cottrell MT, Suttle CA (1991) Wide-spread occurrence and clonal variation in viruses which cause lysis of a cosmopolitan, eukaryotic marine phytoplankter, Micromonas pusilla. Mar Ecol Prog Ser 78:1-9

Gastrich MD, Anderson OR, Benmayor SS, Cosper EM (1998) Ultrastructural analysis of viral infection in the brown-tide alga Aureococcus anophagefferens (Pelagophyceae). Phycologia 37:300-306

Gonzalez JM, Suttle CA (1993) Grazing by marine nanoflagellates on viruses and virus-sized particle: ingestion and digestion. Mar Ecol Prog Ser 94:1-10

Guillard RRL (1975) Culture of phytoplankton for feeding marine invertebrates. In: Smith WL, Chanley $\mathrm{MH}$ (eds) Culture of marine invertebrate animals. Plenum Press, New York, p 29-60

Honjo T (1992) Harmful red tides of Heterosigma akashiwo. NOAA Tech Rep III:27-32

Jacobson A, Bratbak G, Heldal M (1996) Isolation and characterization of a virus infecting Phaeocystis pouchetii (Prymnesiophyceae). J Phycol 32:923-927

Knipe DM (1996) Virus-host cell interactions. In: Fields BM, Knipe DM, Howley PM (eds) Fundamental virology. Lippincott-Raven, Philadephia, PA, p 239-265

Lawrence JE, Chan AM, Suttle CA (2001) A novel virus (HaNIV) causes lysis of the toxic bloom-forming alga, Heterosigma akashiwo (Raphidophyceae). J Phycol 37:1-7

Lawrence JE, Chan AM, Suttle CA (2002) Viruses causing lysis of the toxic bloom-forming alga Heterosigma akashiwo (Raphidophyceae) are widespread in coastal sediments of British Columbia, Canada. Limnol Oceanogr 47:545-550

Nagasaki K, Ando M, Imai I, Itakura S, Ishida Y (1994) Viruslike particles in Heterosigma akashiwo (Raphidophyceae): a possible red tide disintegration mechanism. Mar Biol 119:307-312

Editorial responsibility: Paul Harrison,

Kowloon, Hong Kong
Noble RT, Fuhrman JA (1997) Virus decay and its causes in coastal waters. Appl Environ Microbiol 63:77-83

Padan E, Ginzburg D, Shilo, M (1970) The reproductive cycle of cyanophage LPP1-G in Plectonema boryanum and its dependence on photosynthetic and respiratory systems. Virology 40:514-521

Sherman LA, Haselkorn R (1971) Growth of the blue-green algae virus LPP-1 under conditions which impair photosynthesis. Virology 45:739-746

Sieburth JMcN, Johnson PW, Hargraves PE (1988) Ultrastructure and ecology of Aureococcus anophagefferens gen. et sp. nov. (Chrysophyceae): the dominant picoplankter during a bloom in Narragansett Bay, Rhode Island, summer 1985. J Phycol 24:416-425

Smayda TJ (1970) The suspension and sinking of phytoplankton in the sea. Oceanogr Mar Biol Annu Rev 8: 353-414

Smayda TJ (1998) Ecophysiology and bloom dynamics of Heterosigma akashiwo (Raphidophyceae). In: Anderson DM, Cembella AD, Hallegraeff GM (eds) Physiological ecology of harmful algal blooms. Springer-Verlag, New York, p 113-131

Suttle CA (2000) The ecological, evolutionary and geochemical consequences of viral infection of cyanobacteria and eukaryotic algae. In: Hurst CJ (ed) Viral ecology. Academic Press, London, p 248-286

Suttle CA, Chan AM (1995) Viruses infecting the marine prymnesiophyte Chrysochromulina spp.: isolation, preliminary characterization and natural abundance. Mar Ecol Prog Ser 118:275-282

Suttle CA, Chen F (1992) Mechanisms and rates of decay of marine viruses in seawater. Appl Environ Microbiol 58: 3721-3729

Suttle CA, Chan AM, Cottrell MT (1990) Infection of phytoplankton by viruses and reduction of primary productivity. Nature 347:467-9

Tai V, Lawrence JE, Suttle CA (2003) Characterization of HaRNAV, a novel single-stranded RNA virus causing lysis of the toxic bloom-forming alga, Heterosigma akashiwo (Raphidophyceae). J Phycol 39:343-352

Taruntani K, Nagasaki K, Yamaguchi M (2000) Viral impacts on total abundance and clonal composition of the harmful bloom-forming phytoplankton Heterosigma akashiwo. Appl Environ Microb 66:4916-4921

Taruntani K, Nagasaki K, Itakura S, Yamaguchi M (2001) Isolation of a virus infecting the novel shellfish-killing dinoflagellate Heterocapsa circularisquama. Aquat Microb Ecol 23:103-111

Walsh JJ (1983) Death in the sea: enigmatic phytoplankton losses. Prog Oceanogr 12:1-86

Wilhelm SW, Suttle CA (1999). Viruses and nutrient cycles in the sea. BioScience 49:781-788

Yamochi S (1984) Mechanisms for outbreak of Heterosigma akashiwo red tide in Osaka Bay, Japan. J Oceanogr Soc Jpn 40:343-348

Yamochi S (1989) Mechanisms for outbreak of Heterosigma akashiwo red tide in Osaka Bay, Japan. In: Okaichi, Anderson, Nemoto (eds) red tides: biology, environmental science, and toxicology. Elsevier, New York, p 253-256

Yamochi S, Abe T (1984) Mechanisms to initiate a Heterosigma akashiwo red tide in Osaka Bay. II. Diel vertical migration. Mar Biol 83:255-261

Submitted: December 8, 2003; Accepted: April 3, 2004

Proofs received from author(s): October 6, 2004 